\title{
SIGILO DE DADOS: O DIREITO À PRIVACIDADE E OS LIMITES À FUNÇÃO FISCALIZADORA DO ESTADO
}

\author{
Tércio Sampaio Ferraz Júnior \\ Professor Titular do Departamento de Filosofia e Teoria Geral do Direito \\ da Faculdade de Direito da Universidade de São Paulo
}

\begin{abstract}
Resumo:
A privacidade é regida pelo princípio da exclusividade, cujos atributos principais são a solidão (o estar-só), o segredo, a autonomia. $\mathrm{Na}$ intimidade protege-se sobretudo o estar-só; na vida privada, o segredo; em relação à imagem e à honra, a autonomia. A privacidade tem, pois, a ver com a inviolabilidade do sigilo, porém, não significa um impedimento absoluto à autoridade fiscal. $\mathrm{O}$ acesso aos dados é permitido ainda que seja proibida a interceptação da comunicação.
\end{abstract}

\begin{abstract}
:
The right to privacy is governed by the principle of exclusivity, whose main attributes are solitude (being alone), secrecy and autonomy. Intimacy entails the protection of being alone, while private life entails the protection of secrecy in respect to one's image, honor and autonomy. The right to privacy is thus related to the inviolability of secrecy, but does not imply an absolute exclusion of the fiscal authority of the State. Access to undisclosed data is therefore permissible, notwithstand the legal prohibition of the interception of communication.
\end{abstract}

1. O sigilo de dados é uma hipótese nova, trazida pela Constituição Federal de 1988. A inovação trouxe com ela dúvidas interpretativas que merecem, por isso mesmo, uma reflexão mais detida.

2.

A inviolabilidade do sigilo de dados (art. 50, XII) é correlata ao direito fundamental à privacidade (art. 50, X). Em questão está o direito de o indivíduo excluir do conhecimento de terceiros aquilo que a ele só é pertinente e que diz respeito ao seu modo de ser exclusivo no âmbito de sua vida privada. Mister se faz, pois, explicitar a correlação entre sigilo e privacidade, assinalando também o que os distingue. Principiemos com o direito à privacidade.

3. Trata-se de um direito subjetivo fundamental. Como direito subjetivo, manifesta uma estrutura básica, cujos elementos são o sujeito, o 
conteúdo e o objeto. O sujeito é o titular do direito. Em se tratando de um dos direitos fundamentais do indivíduo, o sujeito é toda e qualquer pessoa, física ou jurídica, brasileira ou estrangeira, residente (ou transeunte cf. Mello Filho, p. 20) no País (art. 5o, caput). O conteúdo é a faculdade específica atribuída ao sujeito, que pode ser a faculdade de constranger os outros ou de resistir-lhes (caso dos direitos pessoais) ou de dispor, gozar, usufruir (caso dos direitos reais). A privacidade, como direito, tem por conteúdo a faculdade de constranger os outros ao respeito e de resistir à violação do que lhe é próprio, isto é, das situações vitais que, por dizerem a ele só respeito, deseja manter para si, ao abrigo de sua única e discricionária decisão. O objeto é o bem protegido, que pode ser uma res (uma coisa, não necessariamente física, no caso de direitos reais) ou um interesse (no caso dos direitos pessoais). No direito à privacidade, o objeto é, sinteticamente, a integridade moral do sujeito. Tanto conteúdo quanto objeto são muito claros no art. 12 da Declaração Universal dos Direitos do Homem, de 1948, em que se lê: "Ninguém sofrerá intromissões arbitrárias na sua vida privada, na sua família, no seu domicílio ou na sua correspondência, nem ataques à sua honra e reputação. Contra tais intromissões ou ataques toda pessoa tem direito à proteção da lei". No Brasil, a Lei n. 5.250/67, ainda em vigor (Lei de Imprensa) estabelece responsabilidade civil nos casos de calúnia e difamação se o fato imputado, ainda que verdadeiro, disser "respeito à vida privada do ofendido e a divulgação não foi motivada em razão de interesse público", e a Lei n. 7.232/84

Lei de Informática - protege o sigilo dos dados armazenados, processados e vinculados, que sejam do interesse da privacidade das pessoas (art. 2º, VIII).

A positivação de um direito humano, conforme o demonstra Celso Lafer (p. 241), "nāo elimina, e por vezes exacerba, os problemas práticos de sua tutela". O direito à privacidade tem raízes modernas. No antigo Direito Romano, a oposição entre o público e o privado tinha a ver com a separação entre o que era de utilidade comum e o que dizia respeito à utilidade dos particulares. Com base nesta distinção afirmava-se a supremacia do público sobre o privado. Mas o público, como já se esboçava na Grécia antiga, passando a princípio básico das democracias modernas, é também o que aparece, que é visível a todos, em oposição ao secreto, ao segredo, ao ato de um poder por isso arbitrário, isto é, porque não se mostra. Já o privado é o que pertence à ordem do que não se mostra em público, do que não se informa a todos nem deve ou precisa ser 
transparente, por dizer respeito às exigências vitais de cada indivíduo, impostas pela necessidade de sobrevivência, que circunscreviam o âmbito do privativo.

A distinção entre a esfera pública e a privada, que para os romanos e os gregos era clara, perde nitidez na era moderna. Para aqueles, o privado (privus), que não se confundia com riqueza privada, era o terreno do que era próprio ao homem, como ser jungido ao trabalho e à sobrevivência, à busca de que lhe era útil. Já o público era o âmbito do político, do encontro dos homens para o seu governo. Esta distinção, na era moderna, se vê atravessada pela noção do social, comum tanto ao público (político) como ao privado (familiar). A afirmação generalizada da "sociabilidade" trouxe o problema da distinção entre o social público (área da política) e o social privado (área do econômico, do mercado), donde o aparecimento de duas novas e importantes dicotomias que estão na raiz dos direitos humanos modernos: Estado e sociedade, sociedade e indivíduo. É nesse contexto que surge a privacidade. $O$ social privado, o mercado, passa a exigir a garantia de um interesse público (livre concorrência, propriedade privada dos bens de produção) que não se confunda com o governo (política), embora dele precise. Mas contra a presença abrangente e avassaladora do mercado que nivela os homens à mercadoria, contrapõe-se a privacidade do indivíduo (Ferraz, p. 131).

4. Analisando-se, pois, o público e o privado na sua acepção contemporânea, deve-se reconhecer que o público-político é dominado pelo princípio da transparência e da igualdade; já o social-privado está sob o domínio do princípio da diferenciação (no sentido do direito de ser diferente, por exemplo, à maneira de Stuart Mill, p. 70); por fim, o terreno da individualidade privativa é regido pelo princípio da exclusividade.

Este último, expresso por Hannah Arendt com base em Kant (cf. Celso Lafer, p. 267), visa a assegurar ao indivíduo a sua identidade diante dos riscos proporcionados pela niveladora pressão social e pela incontrastável impositividade do poder político. Aquilo que é exclusivo é o que passa pelas opções pessoais, afetadas pela subjetividade do indivíduo e que não é dominada nem por normas nem por padrões objetivos. $O$ princípio da exclusividade comporta três atributos principais: a solidão (donde o desejo de estar só), o segredo (donde a exigência de sigilo) e a autonomia (donde a liberdade de 
decidir sobre si mesmo como centro emanador de informações). No recôndito da privacidade se esconde, pois, em primeiro lugar, a intimidade. A intimidade não exige publicidade, porque não envolve direitos de terceiros. No âmbito da privacidade, a intimidade é o mais exclusivo dos seus direitos. Há, porém, uma certa gradação nos direitos da privacidade. Também o direito ao nome, à imagem, à reputação compõem o campo da privacidade. A imagem, a reputação, o nome, à diferença da intimidade, são exclusivos (próprios), mas perante os outros. Como direito à privacidade, demarcam a individualidade em face dos outros. Ninguém tem um nome, uma imagem, uma reputação só para si mesmo, mas como condição de comunicação. Contudo, embora sejam de conhecimento dos outros, que deles estão informados, não podem transformar-se em objeto de troca do mercado, salvo se houver consentimento. Segue-se daí que o princípio da exclusividade, que rege o direito à privacidade, aplica-se diferentemente aos seus objetos específicos. Assim, o inciso X do art. $5^{\circ}$ da Constituição, ao tornar invioláveis a intimidade, a vida privada, a honra e a imagem das pessoas, assegura-lhes o domínio exclusivo em vários sentidos. Embora os comentadores não vejam diferença entre vida privada e intimidade (cf. Ferreira Filho, p. 35, Cretella Júnior, p. 257), pode-se vislumbrar um diferente grau de exclusividade entre ambas. A intimidade é o âmbito do exclusivo que alguém reserva para si, sem nenhuma repercussão social, nem mesmo ao alcance de sua vida privada que, por mais isolada que seja, é sempre um viver entre os outros (na família, no trabalho, no lazer em comum). Não há um conceito absoluto de intimidade, embora se possa dizer que o seu atributo básico é o estar-só, não exclui o segredo e a autonomia. Nestes termos, é possível exemplificá-la: o diário íntimo, o segredo sob juramento, as próprias convições, as situações indevassáveis de pudor pessoal, o segredo íntimo cuja mínima publicidade constrange. Já a vida privada envolve a proteção de formas exclusivas de convivência. Trata-se de situações em que a comunicação é inevitável (em termos de relação de alguém com alguém que, entre si, trocam mensagens), das quais, em princípio, são excluídos terceiros. Seu atributo máximo é o segredo, embora inclua também a autonomia e, eventualmente, o estar-só com os seus. Terceiro é, por definição, o que não participa, que não troca mensagens, que está interessado em outras coisas. Numa forma abstrata, o terceiro compõe a sociedade, dentro da qual a vida privada se desenvolve, mas que com esta não se confunde (cf. Luhmann). A 
vida privada pode envolver, pois, situações de opção pessoal (como a escolha do regime de bens no casamento) mas que, em certos momentos, podem requerer a comunicação a terceiros (na aquisição, por exemplo, de um bem imóvel). Por aí ela difere da intimidade, que não experimenta esta forma de repercussão. Já a honra e a imagem têm um sentido comunicacional, que inevitavelmente envolve terceiros. Ambos, especialmente a imagem, são situações personalíssimas perante os outros. Direito à honra é, assim, direito de sustentar o modo pelo qual cada um supõe e deseja ser bem-visto pela sociedade. É uma combinação entre autorespeito e respeito dos outros. A honra se projeta na imagem que, embora de alguém, é sempre como alguém julga e quer aparecer para os outros. Deve-se dizer, nestes termos, que seu atributo básico é a autonomia. $O$ direito à imagem é o direito de não vê-la mercantilizada, usada, sem o seu exclusivo consentimento, em proveito de outros interesses que não os próprios. Por último, embora graduando-se nos diferentes objetos, o princípio da exclusividade tem, perante todos, um mesmo propósito: a integridade moral do indivíduo, aquilo que faz de cada um o que é e, desta forma, lhe permite inserir-se, na vida social e na vida pública.

5. Pelo exposto, o direito à privacidade não é propriamente um gênero do, mas tem a ver com o direito à inviolabilidade do domicilio (estar-só), da correspondência (segredo), etc. Pontes de Miranda (p. 360) vê na inviolabilidade da correspondência e do segredo profissional um direito fundamental de "negação", uma liberdade de "negação": liberdade de não emitir pensamento exceto para um número reduzido (segredo da correspondência circular, dos avisos reservados aos empregados, etc.) ou exceto para um (cartas particulares). Como direito subjetivo fundamental aqui também há de se distinguir entre o objeto e o conteúdo. $O$ objeto, o bem protegido, é, no dizer de Pontes, a liberdade de "negação" de comunicação do pensamento. $O$ conteúdo, a faculdade específica atribuída ao sujeito, é a faculdade de resistir ao devassamento, isto é, de manter o sigilo (da informação materializada na correspondência, na telegrafia, na comunicação de dados, na telefonia). A distinção é importante. Sigilo não é o bem protegido, não é o objeto do direito fundamental. Diz respeito à faculdade de agir (manter sigilo, resistir ao devassamento), conteúdo estrutural do direito. 
Como faculdade, a manutenção do sigilo não está a serviço apenas da liberdade individual de "negação" de comunicação. Serve também à sociedade e ao Estado. Veja-se, a propósito, o inciso XXXIII do art. $5^{9}$ da C.F., que assegura a todos receber, dos órgãos públicos, informações de seu interesse particular, ou de interesse coletivo ou geral, "ressalvadas aquelas cujo sigilo seja imprescindivel à segurança da sociedade e do Estado". Aqui o sigilo é faculdade (conteúdo) atribuída à sociedade e ao Estado (sujeitos), em proteção de sua segurança (objeto). Seria, portanto, um equívoco falar em direito ao sigilo, tomando a faculdade (conteúdo) pelo bem protegido (objeto), como se se tratasse em si de um único direito fundamental. Ao contrário, é preciso ver e reconhecer que o sigilo, a faculdade de manter sigilo, diz respeito a informações privadas (inciso XII do art. $5 \%$ ) ou de interesse da sociedade ou do Estado (inciso XXXIII do mesmo artigo). No primeiro caso, o bem protegido é uma liberdade de "negação". No segundo, a segurança coletiva.

6.

A liberdade de "negação" de informar o próprio pensamento tem a ver com a privacidade. Ninguém pode ser constrangido a informar sobre a sua privacidade. A liberdade de omitir informação privativa é, porém, também um fato que tem por limite a liberdade de comunicar uma informação privativa: esta possibilidade é um fato que está na base da denúncia e do comportamento do denunciante. Diante deste fato a Constituição garante o sigilo profissional, isto é, a faculdade de resistir ao devassamento de informações mesmo ilegais que o sujeito, em razão de sua profissão, pode lhe ver confiadas (art. $5^{\circ}$, XIV). Nem todo ofício, porém, está protegido pelo sigilo profissional:-só aquele que, por sua natureza, exige a confidência ampla no interesse de quem confidencia. É o caso do médico, do advogado, do padre, do psicólogo, etc. Nos demais casos, a denúncia é uma possibilidade e até uma exigência. Note-se, pois, que a faculdade de resistir ao devassamento (de manter sigilo), conteúdo estrutural de diferentes direitos fundamentais, não é um fim em si mesmo, parte indiscernível de um direito fundamental (uma espécie de direito fundamental da pessoa ao sigilo), mas um instrumento fundamental, cuja essência é a assessoriedade. A inviolabilidade do sigilo, como tal, pode garantir o indivíduo e sua privacidade, ou a privacidade de terceiros, ou ainda a segurança da sociedade e do Estado. No campo da privacidade, pode garantir a confidência, mesmo ilegal, que o 
profissional ouve em razão de ofício. Mas não acoberta a ilegalidade perpetrada no âmbito da privacidade e da qual alguém, sem violência física ou mental, tem notícia.

A inviolabilidade do sigilo, não sendo faculdade exclusiva da privacidade (é também da segurança da sociedade e do Estado), é conditio sine qua non (condição), mas não é conditio per quam (causa) do direito fundamental à privacidade. Ou seja, se não houver inviolabilidade do sigilo não há privacidade, mas se houver inviolabilidade do sigilo isto não significa que haja privacidade (pode haver outra coisa, como a segurança do Estado ou da sociedade). $\mathrm{O}$ direito à privacidade, em consequiência, sendo um fundamento em si mesmo, permite dizer que a privacidade de um indivíduo só se limita pela privacidade de outro indivíduo (como a liberdade de um só encontra limite na liberdade do outro). $\mathrm{O}$ mesmo, porém, não vale para a inviolabilidade do sigilo, cuja instrumentalidade remete à avaliação ponderada dos fins, à chamada "Abwägung" (sopesamento) da dogmática constitucional alemã (Grabitz, p. 5).

A Constituição (art. $5^{\circ}, \mathrm{XII}$ ) ressalva a investigação criminal ou instrução processual, bem como, em caso de estado de defesa (art. 136, §1으, I, b, c) e no estado de sítio (art. 139, III) possíveis restrições ao sigilo da correspondência e das comunicações. Por outro lado, no sentido inverso, a publicidade dos atos processuais (visibilidade da coisa pública) é limitada pela intimidade: a lei pode exigir sigilo (art. 5o, LX), do mesmo modo que a publicidade das informações de interesse particular ou de interesse coletivo ou geral é limitada pelo sigilo necessário à segurança da sociedade e do Estado (art. $5^{\circ}$, XXXIII). Já por aí se observa que o direito à inviolabilidade do sigilo (faculdade) exige o sopesamento dos interesses do indivíduo, da sociedade e do Estado (objeto). Há casos em que a própria Constituição, como vimos, faz o sopesamento. Mas há outros em que o sopesamento aponta para outras relações possíveis, nomeadamente, entre o direito ao sigilo e o dever de sigilo.

Tudo isso mostra, em síntese, que, quando a Constituição garante a inviolabilidade do sigilo, o princípio do sopesamento exige que o intérprete saiba distinguir entre o devassamento que fere o direito à privacidade, no seu objeto, em relação com outros objetos de outros direitos também protegidos pelo sigilo. 
Feita, pois, a distinção entre a faculdade de manter sigilo e a liberdade de omitir informação, este, objeto correlato ao da privacidade, e entendido que aquela não é uma faculdade absoluta, pois compõe, com diferentes objetos, diferentes direitos subjetivos, exigindo do intérprete o devido temperamento, cumpre agora, na análise do texto constitucional, esclarecer, com referência ao art. $5^{\circ}$, XII, que significam ali os dados protegidos pelo sigilo e em que condições e limites ocorre esta proteção.

8. Em primeiro lugar, a expressão "dados" manifesta uma certa impropriedade (Celso Bastos \& Ives Gandra, p. 73). Os citados autores reconhecem que por "dados" não se entende o objeto de comunicação, mas uma modalidade tecnológica de comunicação. Clara, nesse sentido, a observação de Manoel Gonçalves Ferreira Filho (p. 38): "Sigilo de dados. $O$ direito anterior não fazia referência a essa hipótese. Ela veio a ser prevista, sem dúvida, em decorrência do desenvolvimento da informática. Os dados aqui são os dados informáticos (v. incs. XIV e LXXII)". A interpretação faz sentido. O sigilo, no inciso XII do art. $5^{\circ}$, está referido à comunicação, no interesse da defesa da privacidade. Isto é feito, no texto, em dois blocos: a Constituição fala em sigilo "da correspondência e das comunicações telegráficas, de dados e das comunicaçōes telefônicas". Notese, para a caracterização dos blocos, que a conjunção $e$ une correspondência com telegrafia, segue-se uma vírgula e depois, a conjunção de dados com comunicações telefônicas. Há uma simetria nos dois blocos. Obviamente o que se regula é comunicação por correspondência e telegrafia, comunicação de dados e telefonia. $O$ que fere a liberdade de omitir pensamento é, pois, entrar na comunicação alheia, fazendo com que o que devia ficar entre sujeitos que se comunicam privadamente passe ilegitimamente ao domínio de um terceiro. Se alguém elabora para si um cadastro sobre certas pessoas, com informações marcadas por avaliações negativas, e o torna público, poderá estar cometendo difamação, mas não quebra sigilo de dados. Se estes dados, armazenados eletronicamente, são transmitidos, privadamente, a um parceiro, em relações mercadológicas, para defesa do mercado, também não estará havendo quebra de sigilo. Mas se alguém entra nesta transmissão, como um terceiro que nada tem a ver com a relação comunicativa, ou por ato próprio ou porque uma das partes lhe cede o acesso indevidamente, estará violado o sigilo de dados. 
A distinção é decisiva: o objeto protegido no direito à inviolabilidade do sigilo não são os dados em si, mas a sua comunicação restringida (liberdade de negação). A troca de informações (comunicação) privativa é que não pode ser violada por sujeito estranho à comunicação. Doutro modo, se alguém, não por razões profissionais, ficasse sabendo legitimamente de dados incriminadores relativos a uma pessoa, ficaria impedido de cumprir o seu dever de denunciá-los!

9.

Ainda que nos pareça claro o assunto, sua explicação merece um detalhamento. Admitimos, em resumo, que o inciso XII do art. 5o da C.F. trata, em síntese, do direito à inviolabilidade do sigilo da comunicação, o qual tem por conteúdo a faculdade de manter sigilo e por objeto a liberdade de negação. A faculdade referida significa, para o sujeito, que ele pode restringir os endereçados do seu ato comunicativo e, em decorrência, para os demais (os outros) vigora um veto à entrada nessa comunicação, sem consentimento do sujeito - emissor e receptor da mensagem. Quando, pois, alguém um outro intercepta uma mensagem, por exemplo abre uma carta que não lhe foi endereçada, comete uma violência contra a faculdade de manter sigilo e viola a liberdade de negação. Não importa se, na carta, esteja apenas a reprodução de um artigo de jornal publicado na véspera. $O$ direito térá sido violado de qualquer modo, pois a proteção não é para o que consta da mensagem (tecnicamente, o chamado relato comunicado), mas para a ação de enviá-la e recebê-la.

Visto deste ângulo, toma seu correto sentido o disposto no inciso XII do art. $5^{0}$ da C.F. quando ali se admite, apenas para a comunicação telefônica e, assim mesmo, só para fins de investigação criminal ou instrução processual penal, por ordem judicial, a quebra do sigilo. Conquanto haja quem caminhe para uma interpretação literal deste texto, não nos parece razoável aceitá-la na sua inteira singeleza. Note-se, antes de mais nada, que dos quatro meios de comunicação ali mencionados - correspondência, telegrafia, dados, telefonia - só o último se caracteriza por sua instantaneidade. Isto é, a comunicação telefônica só é enquanto ocorre. Encerrada, não deixa vestígios no que se refere ao relato das mensagens e aos sujeitos comunicadores. É apenas possível, a posteriori, verificar qual unidade telefônica ligou para outra. A gravação de conversas telefônicas por meio chamado "grampeamẹto" é, pois, 
uma forma subreptícia de violação do direito ao sigilo da comunicação mas, ao mesmo tempo, é a única forma tecnicamente conhecida de preservar a ação comunicativa. Por isso, no interesse público (investigação criminal ou instrução processual penal), é o único meio de comunicação que exigiu, do constituinte, uma ressalva expressa. Os outros três não sofreram semelhante ressalva porque, no interesse público, é possível realizar investigações e obter provas com base em vestígios que a comunicação deixa: a carta guardada, o testemunho de quem leu o nome do endereçado e do remetente, ou de quem viu a destruição do documento, o que vale também para o telegrama, para o telex, para o telefax, para a recepção da mensagem de um computador para outro, etc.

Como isto é tecnicamente possível, o constituinte não permitiu absolutamente a entrada de terceiros, ainda que em nome do interesse público, na comunicação.

Esta proibição, porém, não significa que, no interesse público, não se possa ter acesso a posteriori à identificação dos sujeitos e ao relato das mensagens comunicadas. Por exemplo, o que se veda é uma autorização judicial para interceptar correspondência, mas não para requerer busca e apreensão de documentos. Esta observação nos coloca, pois, claramente, que a questão de saber quais elementos de uma mensagem podem ser fiscalizados não se confunde com a questão de saber se e quando uma autoridade pode entrar no processo comunicativo entre dois sujeitos. São coisas distintas que devem ser examinadas distintamente. Assim, por exemplo, solicitar ao juiz que permita à autoridade acesso à movimentação bancária de alguém não significa pedir para interceptar suas ordens ao banco (sigilo da comunicação) mas acesso a dados armazenados (sigilo da informação).

A primeira solicitação - salvo se o meio for o telefone é inadmissível; já a segunda é possível. Em que limites?

10. A análise do inciso $\mathrm{X}$ do art. $5^{9}$ da Constituição nos orienta a resposta: são aquelas informações, em termos de privacy, constitutivas da integridade moral da pessoa. No que tange à intimidade, é a informação daqueles dados que a pessoa guarda para si e que dão consistência à sua pessoalidade dados de foro íntimo, expressões de auto-estima, avaliações personalíssimas com respeito a outros, pudores, enfim dados que, quando constantes de processos 
comunicativos, exigem do receptor extrema lealdade e alta confiança, e que, se devassados, desnudariam a personalidade, quebrariam a consistência psíquica, destruindo a integridade moral do sujeito. Em termos do princípio da exclusividade, diríamos que esta é, nesses casos, de grau máximo. Em conseqüência, o emissor pode comunicar tais dados, se o desejar, mas a ninguém é dado exigir dele a informação transmitida, salvo em casos especialíssimos em que a intimidade de alguém venha a interferir na intimidade de outrem: o direito de não ser obrigado a revelar situações íntimas é limitado pelo direito de o receptor recusar informações íntimas que lhe firam a própria intimidade. Por isso, em processos que versem situações íntimas, a lei garante o sigilo. A inexigibilidade desses dados, salvo quando alguém se vê por eles ferido na sua própria intimidade, faz deles um limite ao direito de acesso à informação (art. 5o, XIV da C.F.).

No que diz respeito à vida privada, é a informação de dados referentes às opções da convivência, como a escolha de amigos, a freqüência de lugares, os relacionamentos civis e comerciais, ou seja, de dados que, embora digam respeito aos outros, não afetam, em princípio, direitos de terceiros (exclusividade da convivência). Pelo sentido inexoravelmente comunicacional da convivência, a vida privada compõe, porém, um conjunto de situações que, usualmente, são informadas sem constrangimento. São dados que, embora privativos - como o nome, endereço, profissão, idade, estado civil, filiação, número de registro público oficial, etc. -, condicionam o próprio intercâmbio humano em sociedade, pois constituem elementos de identificação que tornam a comunicação possível, corrente e segura. Por isso, a proteção desses dados em si, pelo sigilo, não faz sentido. Assim, a inviolabilidade de dados referentes à vida privada só tem pertinência para aqueles associados aos elementos identificadores usados nas relações de convivência, as quais só dizem respeito aos que convivem. Dito de outro modo, os elementos de identificação só são protegidos quando compõem relaçōes de convivência privativas: a proteção é para elas, não para eles. Em conseqüência, simples cadastros de elementos identificadores (nome, endereço, R.G., filiação, etc.) não são protegidos. Mas cadastros que envolvam relações de convivência privadas (por exemplo, nas relações de clientela, desde quando é cliente, se a relação foi interrompida, as razões pelas quais isto ocorreu, quais os interesses peculiares do cliente, sua capacidade de satisfazer 
aqueles interesses, etc.) estão sob proteção. Afinal, o risco à integridade moral do sujeito, objeto do direito à privacidade, não está no nome, mas na exploração do nome, não está nos elementos de identificação que condicionam as relações privadas, mas na apropriação dessas relações por terceiros a quem elas não dizem respeito. Pensar de outro modo seria tornar impossível, no limite, o acesso ao registro de comércio, ao registro de empregados, ao registro de navio, etc., em nome de uma absurda proteção da privacidade.

Por último, a honra e a imagem. A privacidade, nesse caso, protege a informação de dados que envolvam avaliações (negativas) do comportamento que, publicadas, podem ferir o bom nome do sujeito, isto é, o modo como ele supõe e deseja ser visto pelos outros. Repita-se que o direito à privacidade protege a honra, o direito à inviolabilidade do sigilo de dados protege a comunicação referente a avaliações que um sujeito faz sobre outro e que, por interferir em sua honra, comunica restritivamente, por razões de interesse pessoal. É o caso, por exemplo, de cadastros pessoais que contêm avaliações negativas sobre a conduta (mau pagador, devedor impontual e relapso, etc.). No tocante à imagem, para além do que ela significa de boa imagem, assimilando-se, nesse sentido, à honra, a proteção refere-se a dados que alguém fornece a alguém e não deseja ver explorada (comercialmente, por exemplo) por terceiros.

11. Feitas estas observações, é oportuno perguntar, em que limites a autoridade fiscal pode exercer sua atuação fiscalizadora, no que diz respeito ao disposto nos incisos X e XII do art. $5^{\circ}$ da C.F.

$\mathrm{O}$ art. 174 da Constituição determina que o Estado, como agente normativo e regulador da atividade econômica, exerça, dentre outras, a função de fiscalização, na forma da lei. Fiscalizar, um dos sentidos da palavra controlar (cf. Fábio Comparato, p. 14), significa vigiar, verificar e, nos casos de anormalidade, censurar (Caldas Aulete: verbete fiscalizar). Fiscalização é, pois, vigilância, donde verificação continuada e, detectada a anormalidade, é censura. $\mathrm{O}$ acesso continuado a informações faz parte da fiscalização. Sem isso não há vigilância. $\mathrm{O}$ acesso intermitente, na verificação da anormalidade, faz parte da censura, que implica castigo, punição.

A competência da administração fazendária para o exercício da função fiscalizadora encontra embasamento constitucional em vários dispositivos. 
Por exemplo, na prevenção (vigilância) e repressão (censura) do contrabando e do descaminho, em sua área de competência, ela é afirmada no art. $144, \S 1^{\circ}$, II. Já o art. $145, \S 1^{\circ}$, ao estabelecer o princípio da capacidade contributiva conforme o qual os impostos, sempre que possível, devem ter caráter pessoal e ser graduados, faculta à administração tributária, "especialmente para conferir efetividade a esses objetivos, identificar, respeitados os direitos individuais e nos termos da lei, o patrimônio, os rendimentos $e$ as atividades econômicas do contribuinte". Esta faculdade de identificar está ligada à implementação de um princípio. Note-se que o constituinte usa a expressão especialmente para conferir a faculdade referida. Este advérbio, em português, significa "de modo especial; particularmente; principalmente; nomeadamente" (Aulete: verbete especialmente). Ou seja, pode significar exclusivamente (só para aquela espécie) ou principalmente (sobretudo, mas não só para aquela espécie). Ora, tendo em vista a função fiscalizadora da administração tributária, parece-nos que o advérbio está usado no segundo e não no primeiro sentido. Ou seja, o constituinte, de um lado, escreveu especialmente porque a mencionada faculdade de identificar não é de presunção óbvia para o efeito de assegurar efetividade àquele princípio e, se não fosse aí inscrita, não se poderia inferir a sua autorização. De outro lado, porque o fez expressamente, admitiu, ao fazê-lo, implicitamente e a contrario sensu que a identificação de patrimônio, rendimento e atividades econômicas do contribuinte é uma presunção da função fiscalizadora da administração tributária. Interpretar de outro modo é tornar impossível a exigência de declaração de bens, de rendimentos, etc.

Por cautela, embora isso nem fosse preciso, o dispositivo exige respeito aos direitos individuais. Ademais que a identificação se faça nos termos da lei. Isto vale tanto para o caso especial, como para a fiscalização em geral.

No que se refere à fiscalização em geral, vale, em termos legais, o disposto nos arts. 194, 195, 196, 197, 198, 199 e 200 do CTN. Mencione-se ainda o art. 12 da Lei Complementar n. 70/91. Em especial, o art. 197 fala de informações com relação a bens, negócios ou atividades de terceiros. $\mathrm{E}$ aí inclui bancos, entre as entidades obrigadas a prestar, mediante intimação escrita, as informações.

Pergunta-se se estas autorizações legais estariam revogadas pelo art. $5^{\circ}$, XII da C.F. combinado com o inciso X. Não nos parece plausível admiti- 
lo pelo absurdo a que ela conduz. Isto significaria acabar com a competência fiscalizadora do Estado. Ora, como vimos, o inciso XII (proteção à comunicação de dados) impede o acesso à própria ação comunicativa, mas não aos dados comunicados.

E estes, protegidos pela privacidade, não constituem um limite absoluto. Tanto que, ainda recentemente, o Ministro Carlos Mário Velloso, relator de decisão que tinha por objeto o sigilo bancário, não teve dúvidas em afirmar, que não se trata de "um direito absoluto, devendo ceder, é certo, diante do interesse público, do interesse da justiça, do interesse social, conforme aliás tem decidido esta Corte" (grifei; segue copiosa citação da jurisprudência do STF e da doutrina cf. STF, Sessão Plenária, ac. de 25.03.92). Do mesmo modo, no mundo financeiro internacional, já se notam importantes mudanças no conceito de sigilo bancário quando estão envolvidas atividades criminosas (Spencer).

12. No tocante, pois, às informações sobre terceiros, exigiveis de instituições financeiras, quando protegidas pela inviolabilidade de sigilo de dados (sigilo bancário), podem ter acesso, observadas as cautelas e formalidades prescritas pela lei, as autoridades e agentes fiscais. $\mathrm{O}$ art. $38, \S 5 \%$ da Lei $\mathrm{n}$. 4.595/46 exige, para isso, processo instaurado (art. 196 do CTN) e que os dados requisitados sejam considerados indispensáveis pela autoridade competente. Não se trata de sigilo profissional (art. $5^{\circ}$, XIV da C.F.) que, na palavra autorizada de Aliomar Baleeiro, não alcança a profissão de banqueiro (p. 550). Em questão está o sigilo de dados privativos (art. $5^{2}, \mathrm{X}$ e XII da C.F.). A nosso ver, com ressalva de dados referentes à intimidade dos sujeitos, os dados da vida privada são acessíveis às autoridades fiscais nas condições e com as cautelas estabelecidas pela lei. Havendo processo administrativo instaurado e sob o sigilo a que o próprio Fisco está obrigado, devem ser reveladas pela instituição financeira intimada as informações consideradas indispensáveis, pela autoridade fiscalizadora, ao exercício de sua função.

O que se diz para a instituição financeira vale, a fortiori, para entidades não protegidas pelo chamado sigilo bancário, como as mencionadas no art. 12 da Lei Complementar n. 70/91, cuja fiscalização se rege, sem as restrições da Lei n. 4.595/64, pelo CTN e pela legislação tributária específica a cada tributo. 
13. Até agora falamos da fiscalização intermitente, que procede mediante processo instaurado. Resta-nos examinar o teor do art. 12 da Lei Complementar n. 70/91, cujo texto dispõe:

"Art. 12. Sem prejuizo do disposto na legislação em vigor, as instituições financeiras, as sociedades corretoras e distribuidoras de títulos e valores mobiliários, as sociedades de investimento $e$ as de arrendamento mercantil, os agentes do Sistema Financeiro da Habitação, as bolsas de valores, de mercadorias, de futuros $e$ instituições assemelhadas $e$ seus associados, e as empresas administradoras de cartão de crédito fornecerāo à Receita Federal, nos termos estabelecidos pelo Ministro da Economia, Fazenda e Planejamento, informações cadastrais sobre os usuários dos respectivos serviços, relativas ao nome, à filiação, ao endereço e ao número de inscriçāo do cliente no Cadastro de Pessoas. Físicas - CPF ou no Cadastro Geral de Contribuintes - CGC.

$\S 1^{9}$. Às informaçōes recebidas nos termos deste artigo aplica-se o disposto no $\$ 7^{\circ}$ do art. 38 da Lei $n^{\circ}$ 4.595, de 31 de dezembro de 1964.

$\S 2$. As informações de que trata o caput deste artigo serāo prestadas a partir das relaçōes de usuários constantes dos registros relativos ao ano-calendário de 1992.

§ 32. A não-observância ao disposto neste artigo sujeitará $o$ infrator, independentemente de outras penalidades administrativas, à multa equivalente a trinta e cinco unidades de valor referidas no art. $5^{9}$ desta Lei Complementar, por usuário omitido".

Como se vê está aqui a possibilidade de se exigirem informações cadastrais relativas a nome, filiação, endereço e número de inscrição no CPF ou CGC. Este tipo de dado (que, por sinal, acrescido de outras informações de 
duvidosa constitucionalidade chega a ser comercializado no negócio chamado mala direta), conforme fizemos ver anteriormente, embora privativo do sujeito, é condição de sua identificação para efeito dos intercâmbios sociais que ocorrem inclusive na vida privada. Destacados dos intercâmbios privados, eles não estão protegidos pela privacidade. Isto vem sendo reconhecido pela jurisprudência, no caso até mais estrito do sigilo bancário, como se observa em diversos julgados, nos quais cadastros de que constem apenas os chamados dados pessoais (nome, endereço, filiação, número de registro) não são considerados objeto de sigilo. Assim, de há muito decidiu o Tribunal de Justiça de Minas Gerais no julgamento do Mandado de Segurança n. 397 em antigo acórdão de 2.12.53. Nesse sentido, a 20.06.79, também é a manifestação do $2^{2}$ Tribunal de Alçada Cível de São Paulo em aresto relatado pelo Des. Joaquim Francisco, em cujo voto se lê:

"...Ora, o primeiro documento - o relatório do fiscal Milton da Silva Torres - é peça meramente informativa de uso interno do Banco, no processamento de um pedido de financiamento. Demais disso, o interesse das partes exauriu-se nos esclarecimentos obtidos quando da tomada do depoimento daquele fiscal, como testemunha, confirmando que foi o indeferimento do Banco para o custeio de um cafezal a ser erradicado.

Quanto ao segundo documento - cópia do indeferimento do pedido de financiamento feito pelo autor ou pelo Sr. Alcides dos Santos - basta que o Banco informe ao Juizo qual o motivo determinante do indeferimento ou somente confirme o indeferimento, sem remeter peças ou informação que envolvam juízo de valor, a serem resguardadas pelo dever-direito de sigilo bancário" (RT 529/150).

Que este tipo de dado possa ser exigido pela administração fazendária, no exercício da fiscalização intermitente, não há menor dúvida. $\mathrm{O}$ art. 12 da Lei Complementar n. 70/91 refere-se, porém, à fiscalização continuada, em termos de vigilância. $\mathrm{O}$ que se pretende é alcançar, pelo cruzamento de cadastros de nomes, endereços, filiação (para os casos de homonímia) e número 
do CPF ou CGC, pistas que conduzam a eventuais fraudes, como uso de documento fiscal falso, ou de terceiros, etc. $O$ interesse da fiscalização não está, aí, na identificação das relações de convivência próprias da vida privada, mas na identificação de um documento oficial (CPF, CGC) e o respectivo portador. Não se quer atingir o uso do serviço (bancário, de cartão de crédito, etc.), mas a identidade tributária do usuário. É este dado e somente este dado que, não estando protegido pela privacidade, pode ser exigido nos termos do mencionado art. 12, isto é, sem a necessidade de processo instaurado.

Poder-se-ia contra-argumentar que, ao fornecer os elementos identificadores do usuário, a entidade mencionada no art. 12 estaria também fornecendo dados referentes à sua clientela, o que estaria protegido pelo sigilo de dados relativos à vida privada nos dois pólos da relação: quem é o cliente e de quem alguém é cliente. De novo não está em jogo a fiscalização intermitente, mediante processo, para a qual este dado é perfeitamente acessível. Em questão, está a fiscalização-vigilância, isto é, a requisição de cadastros sem a instauração de processo, nos termos do art. 12.

Em primeiro lugar, note-se que a lei não obriga o fornecimento de cadastros, mas de informaçōes cadastrais referentes a nome, filiação, endereço e CPF ou CGC. Ou seja, a lei cuidou de separar a informação relativa à relaçāo de clientela, própria da vida privada, e que consta dos cadastros com seus elementos característicos registro dos dados e esclarecimentos sobre as pessoas ou firmas referentes a seus haveres, garantias que oferecem para os negócios, assiduidade no uso do serviço, preferência por tipos de serviço, referências de outras empresas, etc. da informação sobre nome, endereço, filiação e CPF ou CGC que, tomada isoladamente, não caracteriza a relação de clientela. Em outras palavras, a "informação cadastral" mencionada pela lei não é o cadastro e, no cadastro, por si só, não revela a relação de clientela, não revela o uso do serviço que identifica o usuário como cliente, podendo ser fornecida de modo tecnicamente destacado do cadastro de clientes. Esta é a razão pela qual a jurisprudência exclui essas informações do sigilo bancário e esta a razão pela qual estes dados não devem ser considerados dados da vida privada no sentido dos incisos X e XII do art. $5^{\circ}$ da Constituição Federal.

Em segundo lugar, a doutrina mais autorizada é clara a esse respeito. Veja-se, a propósito, o que diz Covello (p. 93): 
"O fato de a pessoa ser cliente do Banco deve ficar sob sigilo?

A resposta não é tão simples como pode parecer à primeira vista.

Bernardino Gonzaga entende que esse fato é hoje corriqueiro e banal, de modo que a divulgação de que o indivíduo é cliente do estabelecimento bancário não constitui violação do dever de reserva, especialmente porque é difícil, nos dias que correm, alguém não ser cliente de Banco ou näo recorrer ao Banco para obter algum serviço.

Certo é também que muitas vezes esse fato é notório, sendo mesmo comum a hipótese de o próprio cliente propalar a sua condição de cliente de determinado Banco como traço de 'status' ou, então, para fazer do Banco seu agente de cobrança. Certas entidades filantrópicas divulgam até pelos meios de comunicação o número de suas contas bancárias com, o fito de arrecadarem donativos através da instituição financeira. Onde há notoriedade, não há falar em segredo, muito menos em obrigação de segredo a cargo do Banco".

A revelação do nome é muito distinta da revelação do nome aliada ao serviço. É o que nota o mesmo autor, ao comentar:

"Não obstante, é de considerar que, em determinados casos, convém ao cliente ocultar esse informe, como ocorre, por exemplo, quando alguém contrata a locação de cofre de segurança com o estabelecimento de crédito. A maior vantagem desse serviço, além da segurança da custódia, é o seu caráter sigiloso, pois presume-se que o usuário do cofre tenha interesse em ocultar de terceiro a própria circunstância de ter a disponibilidade da caixa de segurança no estabelecimento bancário. Também a custódia de 
títulos e valores e, bem assim, o depósito pecuniário revestem esse mesmo caráter, por isso que, para o Banco, é sempre melhor calar".

Em relação, porém, ao nome, sua posição não deixa dúvida:

"Agora, a revelação de que determinada pessoa se vale dos serviços de caixa do Banco não nos parece constituir violação do segredo, porque esse fato é corriqueiro, nos dias atuais. $O$ Banco não é esconderijo".

14. Não resta dúvida, pelo exposto, que tanto a privacidade quanto a inviolabilidade de sigilo de dados, inseridas no art. 5o da Constituição Federal, são uma peça fundante da própria cidadania, ao lado de outros direitos fundamentais ali expressos. $O$ sigilo, nesse sentido, tem a ver com a segurança do cidadão, princípio cujo conteúdo valorativo diz respeito à exclusão do arbítrio, não só de parte da sociedade como sobretudo do Estado que só pode agir submisso à ordem normativa que o constitui. Nestes termos, a cidadania, exigência do princípio republicano, que a reclama como uma espécie de fundamento primeiro da vida política e, por conseqüência, do Estado, antecede o Estado, não sendo por ele instituída. É ela que constitui a distinção entre o público e o privado, sob pena de perversão da soberania popular (C.F., art. 192, parágrafo único). As competências estabelecidas e atribuídas ao Estado devem, pois, estar submetidas ao reconhecimento do indivíduo como cidadão, cuja dignidade se corporifica em direitos fundamentais.

Por outro lado, o Poder Público não pode ser inibido de exercer suas funções, mormente a de fiscalização, por isso que a própria Constituição, no rol mesmo dos direitos fundamentais, prevê o sigilo para atividades do próprio Estado. Quando o assunto envolve inviolabilidade de sigilo de dados privativos que protege o cidadão, mas não aquele interesse do cidadão cujo sentido social é duvidoso, o dever de fiscalização impổe, como vimos, ao Fisco, na coleta e no tratamento dos dados, igual sigilo. Deste equilibrio interpretativo não escapa o Poder Legislativo. Assim, por exemplo, quando se lê no art. 50, § 2º da C.F., que as Mesas da Câmara dos Deputados e do Senado Federal podem encaminhar 
pedidos escritos de informações aos Ministros de Estado, esta competência tem de sofrer a devida interpretação restritiva. Destarte, deve-se reconhecer que, a propósito, o art. 38 da Lei n. 4.595/64 que, com cautela, exige que pedidos que afetem o sigilo de dados bancários sejam solicitados com aprovação pelo Plenário da Câmara e, quando se tratar de Comissão Parlamentar de Inquérito, pela maioria absoluta de seus membros, foi recebido pela atual Constituição. Esta exigência, de um lado, protege o cidadão, de outro, baliza o modo pelo qual a autoridade pode e deve exercer sua competência.

Assim, o art. 50 da C.F. quando autoriza, no caput, a convocação, pela Mesa, de Ministro de Estado para prestar, pessoalmente, informações sobre assunto previamente determinado e, no seu $\S 2^{2}$, pedidos escritos de informação, é óbvio que os assuntos devem dizer respeito a questões de natureza pública, na órbita da competência federal. Mais especificamente, o art. 50 instrumentaliza o inciso X do art. 49 ("É de competência exclusiva do Congresso Nacional: ... X fiscalizar e controlar, diretamente, ou por qualquer de suas Casas, os atos do Poder Executivo, incluídos os da administraçāo indireta"). Aliás, o próprio Regimento Interno da Câmara dos Deputados, aprovado pela Resolução n. 17, de 21.09.1989, especifica quais assuntos - atos e fatos estão sujeitos à fiscalização e controle do Congresso. Ali se menciona expressamente o art. 70 da C.F. (assuntos passíveis de fiscalização contábil, financeira, orçamentária, operacional e patrimonial da União e das entidades da administração direta e indireta) e, por via de conseqüência implícita, os atos de gestão administrativa do Poder Executivo. Nada autoriza a pensar que neste rol possam estar assuntos referentes à vida privada dos cidadãos.

Inclusive no caso de comissões parlamentares de inquérito, que tem poderes de investigação próprias das autoridades judiciais e, por isso mesmo, são constituídas por requerimento de um terço dos membros do Senado e da Câmara, para a apuração de fato determinado, não se pode esquecer o mandamento do inciso XXXIII do art. $5^{9}$ que assegura direito a informações a todos os cidadãos, "ressalvadas aquelas cujo sigilo seja imprescindível à segurança da sociedade e do Estado". Nestes casos, o fornecimento de dados submetidos a sigilo obriga a autoridade competente à manutenção do próprio sigilo, que sob esta condição, serão encaminhados. 
Por fim, este temperamento das situações, a busca da hermenêutica equilibrada, só favorece o Estado de Direito que não significa um bloqueio do Estado, mas o exercício de sua atividade, no contorno que lhe dá a Constituição, para a realização do próprio bem-estar social.

\section{BIBLIOGRAFIA}

BALEEIRO, Aliomar. Direito tributário brasileiro. 4a ed. Rio de Janeiro : Forense, 1972.

BASTOS, Celso, MARTINS, Ives Gandra. Comentários à Constituição do Brasil.

São Paulo : Saraiva, 1989. v.2.

COMPARATO, Fábio. O poder de controle na sociedade anônima. São Paulo :

Revista dos Tribunais, 1976.

COVELlO, Sergio Carlos. O sigilo bancário. São Paulo : Leud, 1991.

FERRAZ JUNIOR, Tércio Sampaio. Introdução ao estudo do direito. São Paulo : Atlas, 1988.

FERREIRA FILHO, Manoel Gonçalves. Comentários à Constituiçāo Brasileira de 1988. São Paulo : Saraiva, 1990. v. 1.

GRABITZ, Eberhard. Freiheit und Verfassungsrecht. Tübingen : Mohr, 1976.

LAFER, Celso. A reconstrução dos direitos humanos. São Paulo : Companhia das Letras, 1988.

LUHMANN, Niklas. Rechtssoziologie. 2 vs.

MELlo FILHO, José Celso de. Constituição Federal anotada. São Paulo : Saraiva, 1984.

MILL, John Stuart. On liberty. New York-London : W. W. Norton \& Company, 1975.

SPENCER, David E. Capital flight and bank secrecy: the end of an era? International Financial Law Review, London, May, 1992. 